\title{
A Clinical Trial of the Effects of Dietary Patterns on Blood Pressure
}

\section{Citation}

Appel, Lawrence J., Thomas J. Moore, Eva Obarzanek, William M. Vollmer, Laura P. Svetkey, Frank M. Sacks, George A. Bray, et al. 1997. "A Clinical Trial of the Effects of Dietary Patterns on Blood Pressure." New England Journal of Medicine 336 (16) (April 17): 1117-1124. doi:10.1056/ nejm199704173361601.

\section{Published Version}

doi:10.1056/NEJM199704173361601

\section{Permanent link}

http://nrs.harvard.edu/urn-3:HUL.InstRepos:30147220

\section{Terms of Use}

This article was downloaded from Harvard University's DASH repository, and is made available under the terms and conditions applicable to Other Posted Material, as set forth at http:// nrs.harvard.edu/urn-3:HUL.InstRepos:dash.current.terms-of-use\#LAA

\section{Share Your Story}

The Harvard community has made this article openly available.

Please share how this access benefits you. Submit a story.

\section{Accessibility}




\section{The New England Journal of Medicine}

(C) Copyright, 1997, by the Massachusetts Medical Society

\section{A CLINICAL TRIAL OF THE EFFECTS OF DIETARY PATTERNS ON BLOOD PRESSURE}

Lawrence J. Appel, M.D., M.P.H., Thomas J. Moore, M.D., Eva Obarzanek, Ph.D., William M. Vollmer, Ph.D., Laura P. SvetKey, M.D., M.H.S., Frank M. Sacks, M.D., George A. Bray, M.D., Thomas M. Vogt, M.D., M.P.H., Jeffrey A. Cutler, M.D., Marlene M. Windhauser, Ph.D., R.D., Pao-Hwa Lin, Ph.D., and Nueri Karanja, Ph.D., for the DASH Collaborative Research Group*

\begin{abstract}
Background It is known that obesity, sodium intake, and alcohol consumption influence blood pressure. In this clinical trial, Dietary Approaches to Stop Hypertension, we assessed the effects of dietary patterns on blood pressure.

Methods We enrolled 459 adults with systolic blood pressures of less than $160 \mathrm{~mm} \mathrm{Hg}$ and diastolic blood pressures of 80 to $95 \mathrm{~mm} \mathrm{Hg}$. For three weeks, the subjects were fed a control diet that was low in fruits, vegetables, and dairy products, with a fat content typical of the average diet in the United States. They were then randomly assigned to receive for eight weeks the control diet, a diet rich in fruits and vegetables, or a "combination" diet rich in fruits, vegetables, and low-fat dairy products and with reduced saturated and total fat. Sodium intake and body weight were maintained at constant levels.

Results At base line, the mean ( $\pm \mathrm{SD}$ ) systolic and diastolic blood pressures were $131.3 \pm 10.8 \mathrm{~mm} \mathrm{Hg}$ and $84.7 \pm 4.7 \mathrm{~mm} \mathrm{Hg}$, respectively. The combination diet reduced systolic and diastolic blood pressure by 5.5 and $3.0 \mathrm{~mm} \mathrm{Hg}$ more, respectively, than the control diet $(\mathrm{P}<0.001$ for each); the fruits-and-vegetables diet reduced systolic blood pressure by $2.8 \mathrm{~mm} \mathrm{Hg}$ more $(\mathrm{P}<0.001)$ and diastolic blood pressure by 1.1 $\mathrm{mm} \mathrm{Hg}$ more $(P=0.07)$ than the control diet. Among the 133 subjects with hypertension (systolic pressure, $\geqslant 140 \mathrm{~mm} \mathrm{Hg}$; diastolic pressure, $\geqslant 90 \mathrm{~mm} \mathrm{Hg}$; or both), the combination diet reduced systolic and diastolic blood pressure by 11.4 and $5.5 \mathrm{~mm} \mathrm{Hg}$ more, respectively, than the control diet $(\mathrm{P}<0.001$ for each); among the 326 subjects without hypertension, the corresponding reductions were $3.5 \mathrm{~mm} \mathrm{Hg}$ $(\mathrm{P}<0.001)$ and $2.1 \mathrm{~mm} \mathrm{Hg}(\mathrm{P}=0.003)$.

Conclusions A diet rich in fruits, vegetables, and low-fat dairy foods and with reduced saturated and total fat can substantially lower blood pressure. This diet offers an additional nutritional approach to preventing and treating hypertension. (N Engl J Med 1997;336:1117-24.)

(C1997, Massachusetts Medical Society.
\end{abstract}

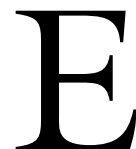
LEVATED blood pressure is a common problem in the United States. Recent survey data indicate that 24 percent of U.S. adults - approximately 43 million people - have hypertension and only 47 percent have optimal blood pressure (systolic blood pressure, $<120 \mathrm{~mm} \mathrm{Hg}$; diastolic blood pressure, $<80 \mathrm{~mm} \mathrm{Hg}$ ). ${ }^{1}$ Among adults 50 years of age or older, a much higher proportion have hypertension and a much lower proportion have optimal blood pressure. Efforts to reduce the prevalence of hypertension have focused on nonpharmacologic approaches that lower blood pressure. Current national guidelines recommend weight control, reduced intake of sodium chloride (salt), reduced alcohol consumption, and possibly increased dietary potassium as nutritional approaches to prevent and treat hypertension. ${ }^{2,3}$

\footnotetext{
From the Welch Center for Prevention, Epidemiology, and Clinical Research, Johns Hopkins University, Baltimore (L.J.A.); the Department of Medicine, Brigham and Women's Hospital, Boston (T.J.M., F.M.S.); Merck and Company, Westwood, Mass. (T.J.M.); the Division of Epidemiology and Clinical Applications, National Heart, Lung, and Blood Institute, Bethesda, Md. (E.O., J.A.C.); Kaiser Permanente Center for Health Research, Portland, Oreg. (W.M.V., T.M.V., N.K.); Duke Hypertension Center (L.P.S.) and the Sarah W. Stedman Center for Nutritional Studies (P.-H.L.), Duke University Medical Center, Durham, N.C.; the Department of Nutrition, Harvard School of Public Health, Boston (F.M.S.); and the Pennington Biomedical Research Center, Baton Rouge, La. (G.A.B., M.M.W.). Address reprint requests to Dr. Vollmer at the Kaiser Permanente Center for Health Research, 3800 N. Kaiser Center Dr., Portland, OR 97227-1098.

Other authors were Denise Simons-Morton, M.D., Ph.D. (National Heart, Lung, and Blood Institute, Bethesda, Md.); Marjorie McCullough, M.S., R.D., and Janis Swain, M.S., R.D. (Brigham and Women's Hospital, Boston); Priscilla Steele, M.S., R.D. (Beltsville Human Nutrition Research Center, U.S. Department of Agriculture, Beltsville, Md.); Marguerite A. Evans, M.S., R.D. (National Heart, Lung, and Blood Institute, Bethesda, Md.); Edgar R. Miller III, M.D., Ph.D. (Johns Hopkins University, Baltimore); and David W. Harsha, Ph.D. (Pennington Biomedical Research Center, Baton Rouge, La.).

${ }^{*}$ Members of the DASH Collaborative Research Group are listed in the Appendix.
} 
Other dietary factors may influence blood pressure. Vegetarians tend to have lower blood pressures than nonvegetarians. ${ }^{4}$ In trials of vegetarian diets, replacing animal products with vegetable products reduced blood pressure in normotensive and hypertensive people. 5,6 Aspects of vegetarian diets believed to reduce blood pressure include their high levels of fiber and minerals (such as potassium and magnesium) and their reduced fat content. In observational studies, significant inverse associations of blood pressure with intake of magnesium, potassium, calcium, fiber, and protein have also been reported. .11 $^{-11}$ However, in trials that tested these nutrients, often as dietary supplements, the reduction in blood pressure has typically been small and inconsistent. ${ }^{12-18}$

There are several possible reasons for the discrepancy between the inconsistent results of trials that modified single nutrients and the generally positive results of trials of vegetarian diets and observational studies of diet and blood pressure. The effect of any individual nutrient in lowering blood pressure may be too small to detect in trials. When several nutrients with small blood-pressure-lowering effects are consumed together, however, the cumulative effect may be sufficient for detection. Alternatively, nutrients other than those tested in trials or measured in observational studies may reduce blood pressure. Also, nutrients in dietary supplements may not reduce blood pressure to the same extent as nutrients in food, because of interactions with other dietary components or because of altered bioavailability.

The Dietary Approaches to Stop Hypertension (DASH) trial was a multicenter, randomized feeding study that tested the effects of dietary patterns on blood pressure. As a trial of dietary patterns rather than individual nutrients, DASH tested the combined effects of nutrients that occur together in food.

\section{METHODS}

A detailed description of the methods of this trial has been published elsewhere. ${ }^{19}$ Institutional review boards at each center and an external protocol-review committee approved the trial protocol. Each DASH participant provided written consent.

\section{Study Subjects}

The study subjects were adults 22 years of age or older who were not taking antihypertensive medication. Each subject had an average systolic blood pressure of less than $160 \mathrm{~mm} \mathrm{Hg}$ and a diastolic blood pressure of 80 to $95 \mathrm{~mm} \mathrm{Hg}$ (the mean of six measurements made during three screening visits). Persons with medication-treated hypertension could enroll if they met the inclusion criteria for blood pressure after supervised withdrawal of medication. The major exclusion criteria were poorly controlled diabetes mellitus; hyperlipidemia; a cardiovascular event within the previous six months; chronic diseases that might interfere with participation; pregnancy or lactation; a body-mass index (the weight in kilograms divided by the square of the height in meters) of more than 35; the use of medications that affect blood pressure; unwillingness to stop taking vitamin and mineral supplements or antacids containing magnesium or calcium; renal insuf- ficiency; and an alcoholic-beverage intake of more than 14 drinks per week. Because of the disproportionate burden of hypertension in minority populations, particularly among blacks, one of the goals of the trial was to recruit a cohort in which two thirds of the subjects were members of a racial or ethnic minority. Mass mailing of brochures and work-site and community-based screenings were the primary recruitment strategies. Study subjects were enrolled sequentially in groups; the first group began the run-in phase of the trial in September 1994, and the fifth and last group started in January 1996.

\section{Conduct of the Trial}

For each group, the trial was conducted in three phases (screening, run-in, and intervention). At each of three screening visits, trained and certified staff members measured the subjects' standard blood pressure with a random-zero sphygmomanometer according to a common protocol used in other trials. ${ }^{12}$ At each visit, a pair of blood-pressure measurements was obtained after the subjects rested for five minutes in the seated position. Systolic blood pressure was measured as the point of appearance (phase I) of Korotkoff sounds; diastolic blood pressure was measured as the point of disappearance (phase V). The Stanford 7-Day Physical Activity Recall questionnaire was administered once during screening. ${ }^{20}$

The run-in phase was a three-week period in which all subjects were given the control diet. During the last two weeks, a pair of blood-pressure measurements was obtained on each of four separate days, one 24-hour urine sample was collected, and a questionnaire on symptoms was completed. The subjects then were randomly assigned to one of three diets during the third week and learned of their diet assignments on the first day of intervention.

The intervention phase was an eight-week period in which the subjects followed their assigned diets. Once each week during the first six weeks, staff members who were blinded to diet assignment measured blood pressure. During the last two weeks, a pair of blood-pressure measurements was obtained on each of five separate days, one 24-hour urine sample was collected, and the symptom questionnaire and physical-activity-recall questionnaire were administered once each.

In the last four of the five enrollment groups, ambulatory blood pressure was recorded at the end of the run-in and intervention periods with the Space Labs 90207 device (Space Labs, Redmond, Wash.). For each recording, mean 24-hour blood pressure was calculated from measurements obtained every 30 minutes.

\section{Diets}

The nutrient composition of the control diet was typical of the diets of a substantial number of Americans. The potassium, magnesium, and calcium levels were close to the 25 th percentile of U.S. consumption, ${ }^{21}$ and the macronutrient profile and fiber content corresponded to average consumption.

The fruits-and-vegetables diet provided potassium and magnesium at levels close to the 75 th percentile of U.S. consumption, along with high amounts of fiber. This diet provided more fruits and vegetables and fewer snacks and sweets than the control diet but was otherwise similar to it.

The combination diet was rich in fruits, vegetables, and low-fat dairy foods and had reduced amounts of saturated fat, total fat, and cholesterol. This diet provided potassium, magnesium, and calcium at levels close to the 75th percentile of U.S. consumption, along with high amounts of fiber and protein. The sodium content of each diet was similar - approximately $3 \mathrm{~g}$ per day. Table 1 shows the nutrient targets of the diets, chemical analyses of the menus prepared at the clinical centers, and the estimated number of servings of food groups per day.

\section{Controlled Feeding}

A seven-day menu cycle with 21 meals at four calorie levels $(1600,2100,2600$, and $3100 \mathrm{kcal})$ was developed for each diet and was identical at all centers. Menus were designed that used 
Table 1. Nutrient Targets, Menu Analyses, and Average Daily Servings of Foods, ACCORDing to Diet.*

\begin{tabular}{|c|c|c|c|c|c|c|}
\hline \multirow[t]{2}{*}{ ITEM } & \multicolumn{2}{|c|}{ Control Diet } & \multicolumn{2}{|c|}{$\begin{array}{c}\text { FruITS-AND- } \\
\text { VEGETABLES DIET }\end{array}$} & \multicolumn{2}{|c|}{ Combination Diet } \\
\hline & $\begin{array}{l}\text { NUTRIENT } \\
\text { TARGET }\end{array}$ & $\begin{array}{c}\text { MENU } \\
\text { ANALYSIS } †\end{array}$ & $\begin{array}{l}\text { NUTRIENT } \\
\text { TARGET }\end{array}$ & $\begin{array}{c}\text { MENU } \\
\text { ANALYSIS } †\end{array}$ & $\begin{array}{l}\text { NUTRIENT } \\
\text { TARGET }\end{array}$ & $\begin{array}{c}\text { MENU } \\
\text { ANALYSIS } †\end{array}$ \\
\hline \multicolumn{7}{|l|}{ Nutrients } \\
\hline Fat $(\%$ of total kcal) & 37 & 35.7 & 37 & 35.7 & 27 & 25.6 \\
\hline Saturated & 16 & 14.1 & 16 & 12.7 & 6 & 7.0 \\
\hline Monounsaturated & 13 & 12.4 & 13 & 13.9 & 13 & 9.9 \\
\hline Polyunsaturated & 8 & 6.2 & 8 & 7.3 & 8 & 6.8 \\
\hline Carbohydrates (\% of total kcal) & 48 & 50.5 & 48 & 49.2 & 55 & 56.5 \\
\hline Protein (\% of total kcal) & 15 & 13.8 & 15 & 15.1 & 18 & 17.9 \\
\hline Cholesterol (mg/day) & 300 & 233 & 300 & 184 & 150 & 151 \\
\hline Fiber (g/day) & 9 & NA & 31 & NA & 31 & NA \\
\hline Potassium (mg/day) & 1700 & 1752 & 4700 & 4101 & 4700 & 4415 \\
\hline Magnesium (mg/day) & 165 & 176 & 500 & 423 & 500 & 480 \\
\hline Calcium (mg/day) & 450 & 443 & 450 & 534 & 1240 & 1265 \\
\hline Sodium (mg/day) & 3000 & 3028 & 3000 & 2816 & 3000 & 2859 \\
\hline \multicolumn{7}{|l|}{ Food groups (no. of servings/day) } \\
\hline Fruits and juices & \multicolumn{2}{|c|}{1.6} & \multicolumn{2}{|c|}{5.2} & \multicolumn{2}{|c|}{5.2} \\
\hline Vegetables & \multicolumn{2}{|c|}{2.0} & \multicolumn{2}{|c|}{3.3} & \multicolumn{2}{|c|}{4.4} \\
\hline Grains & \multicolumn{2}{|c|}{8.2} & \multicolumn{2}{|c|}{6.9} & \multicolumn{2}{|c|}{7.5} \\
\hline Low-fat dairy & \multicolumn{2}{|c|}{0.1} & \multicolumn{2}{|c|}{0.0} & \multicolumn{2}{|c|}{2.0} \\
\hline Regular-fat dairy & \multicolumn{2}{|c|}{0.4} & \multicolumn{2}{|c|}{0.3} & \multicolumn{2}{|c|}{0.7} \\
\hline Nuts, seeds, and legumes & \multicolumn{2}{|c|}{0.0} & \multicolumn{2}{|c|}{0.6} & \multicolumn{2}{|c|}{0.7} \\
\hline Beef, pork, and ham & \multicolumn{2}{|c|}{1.5} & \multicolumn{2}{|c|}{1.8} & \multicolumn{2}{|c|}{0.5} \\
\hline Poultry & \multicolumn{2}{|c|}{0.8} & \multicolumn{2}{|c|}{0.4} & \multicolumn{2}{|c|}{0.6} \\
\hline Fish & \multicolumn{2}{|c|}{0.2} & \multicolumn{2}{|c|}{0.3} & 0 . & .5 \\
\hline Fat, oils, and salad dressing & 5 . & & 5 & .3 & 2 . & .5 \\
\hline Snacks and sweets & 4. & & 1 . & .4 & 0 . & .7 \\
\hline
\end{tabular}

*Values are for diets designed to provide an energy level of $2100 \mathrm{kcal}$.

†Values are the results of chemical analyses of the menus prepared during the validation phase and during the trial. NA denotes not available.

commonly available foods in a variety of forms (fresh, frozen, canned, and dried). Specialty foods with fat substitutes were not used. To standardize the diets, all the centers used the same brand of a given food item.

Food was prepared in research kitchens according to a common protocol. Each weekday, the subjects ate lunch or dinner on site. After the on-site meal, the subjects received coolers containing the food to be consumed off site. On Fridays, they also received weekend meals, all consumed off site. The subjects were instructed to drink no more than three caffeinated beverages and no more than two alcoholic beverages per day. Two packets of salt, each containing $0.2 \mathrm{~g}$ of sodium, were provided daily for discretionary use. Their weight was measured each weekday and was kept stable by changing calorie levels and by adding 100-kcal cookies or muffins with nutrient contents that corresponded to those of the assigned diets.

For each day of controlled feeding, the subjects recorded their intake of discretionary items (beverages and salt). They indicated whether they ate any nonstudy foods and whether they did not eat all the study foods. Procedures for evaluating adherence to the diets were revised after the first group completed the program; hence, data on adherence are presented for the 362 subjects enrolled subsequently. Each center provided reimbursement and incentives to promote adherence.

\section{Outcomes}

The change in diastolic blood pressure at rest was the primary outcome; changes in systolic blood pressure and in ambulatory diastolic and systolic blood pressure were secondary outcomes. A change in blood pressure was the difference between blood pressure at follow-up (the average of four or five pairs of measurements during weeks 7 and 8 of the intervention phase) and base line (the average of three pairs during the screening and four pairs during the run-in phase). For seven subjects without follow-up measurements during the last two weeks, follow-up blood pressure was considered to be the average of earlier intervention measurements. For six subjects without any measurements during the intervention phase, follow-up blood pressure was considered to be the mean blood pressure during screening.

\section{Statistical Analysis}

DASH was designed to test the following alternative hypotheses: that the change in blood pressure would differ between the combination and control diets; that the change in blood pressure would differ between the fruits-and-vegetables and the control diets; and that the change in blood pressure would differ between the combination and the fruits-and-vegetables diets. The target sample size of 456 randomly assigned subjects was estimated to provide 85 percent power to detect a mean between-diet difference of $2 \mathrm{~mm} \mathrm{Hg}$ in diastolic blood pressure. Subgroup analyses according to sex, minority status, and base-line blood pressure were planned; in the latter analyses, the subjects were considered to have hypertension if their base-line systolic blood pressure was 140 $\mathrm{mm} \mathrm{Hg}$ or higher or their diastolic blood pressure was $90 \mathrm{~mm} \mathrm{Hg}$ or higher.

Analyses were performed on an intention-to-treat basis. For primary analyses and within each subgroup stratum, between-diet differences in the change in blood pressure were tested by two-way 
Table 2. Prerandomization Characteristics of the Study Subjects, According to Diet.*

\begin{tabular}{|c|c|c|c|}
\hline CHARACteristics & $\begin{array}{l}\text { Control Diet } \\
(\mathbf{N}=154)\end{array}$ & $\begin{array}{c}\text { FruITS-AND- } \\
\text { VEGETABLES } \\
\text { DIET } \\
(\mathbf{N}=\mathbf{1 5 4})\end{array}$ & $\begin{array}{c}\text { Combination } \\
\text { Diet } \\
(\mathbf{N}=\mathbf{1 5 1})\end{array}$ \\
\hline Age (yr) & $44 \pm 11$ & $45 \pm 11$ & $44 \pm 10$ \\
\hline Female sex (\%) & 47.4 & 48.7 & 51.0 \\
\hline \multicolumn{4}{|l|}{ Race or ethnicity (\%) } \\
\hline Nonminority & 35.1 & 35.7 & 31.1 \\
\hline Black & 59.7 & 58.4 & 61.6 \\
\hline Other minority & 5.2 & 5.8 & 7.3 \\
\hline \multicolumn{4}{|l|}{ Household income (\%) } \\
\hline$<\$ 30,000$ & 37.1 & 36.7 & 36.0 \\
\hline$\$ 30,000-\$ 59,999$ & 41.7 & 36.7 & 42.7 \\
\hline$\geqslant \$ 60,000$ & 21.2 & 26.7 & 21.3 \\
\hline \multicolumn{4}{|l|}{ Weight (kg) } \\
\hline Men & $87.7 \pm 13.7$ & $86.6 \pm 13.9$ & $88.0 \pm 15.7$ \\
\hline Women & $75.4 \pm 12.2$ & $77.1 \pm 12.5$ & $78.9 \pm 11.7$ \\
\hline \multicolumn{4}{|l|}{ Body-mass index $\dagger$} \\
\hline Men & $27.7 \pm 3.6$ & $27.5 \pm 3.6$ & $28.1 \pm 4.0$ \\
\hline Women & $28.3 \pm 4.0$ & $28.9 \pm 4.3$ & $29.0 \pm 3.9$ \\
\hline $\begin{array}{c}\text { Blood-pressure medication } \\
\text { discontinued }(\%)\end{array}$ & 5.8 & 5.8 & 4.6 \\
\hline $\begin{array}{c}\text { Ever received blood-pressure } \\
\text { medication }(\%)\end{array}$ & 20.8 & 25.3 & 20.5 \\
\hline Alcohol (drinks/wk) & $1.3 \pm 2.5$ & $1.1 \pm 2.2$ & $1.3 \pm 2.5$ \\
\hline \multicolumn{4}{|l|}{ Blood pressure } \\
\hline $\begin{array}{l}\text { Systolic }(\mathrm{mm} \mathrm{Hg}) \ddagger \\
\quad \geqslant 140(\%)\end{array}$ & $\begin{array}{l}132 \pm 10.7 \\
24.7\end{array}$ & $\begin{array}{c}132.3 \pm 10.5 \\
25.3\end{array}$ & $\begin{array}{c}131.2 \pm 10.0 \\
20.5\end{array}$ \\
\hline $\begin{array}{l}\text { Diastolic }(\mathrm{mm} \mathrm{Hg}) \ddagger \\
\quad \geqslant 90(\%)\end{array}$ & $\begin{array}{c}85.3 \pm 4.0 \\
14.9\end{array}$ & $\begin{array}{c}84.8 \pm 3.9 \\
14.3\end{array}$ & $\begin{array}{c}85.1 \pm 3.6 \\
11.9\end{array}$ \\
\hline $\begin{array}{l}\text { Ambulatory systolic } \\
(\mathrm{mm} \mathrm{Hg}) \mathbb{S}\end{array}$ & $130.9 \pm 11.3$ & $132.0 \pm 10.8$ & $131.9 \pm 10.7$ \\
\hline $\begin{array}{l}\text { Ambulatory diastolic } \\
(\mathrm{mm} \mathrm{Hg}) \mathfrak{S}\end{array}$ & $83.3 \pm 7.4$ & $83.9 \pm 8.0$ & $83.6 \pm 6.8$ \\
\hline
\end{tabular}

*Plus-minus values are means \pm SD.

$\dagger$ The body-mass index is the weight in kilograms divided by the square of the height in meters.

$\ddagger$ Values are the means for three screening visits.

SValues are the mean 24-hour blood pressures in the subjects in enrollment groups 2 to 5 (control $[n=118]$, fruits-and-vegetables $[n=121]$, and combination $[\mathrm{n}=115]$ diets).

analysis of variance, with adjustment for clinical center. To adjust for multiple comparisons, a between-diet difference was considered statistically significant at $\mathrm{P}<0.025$ (two-tailed); hence, 97.5 percent confidence intervals are given for between-diet differences.

\section{RESULTS}

Of a total of 8813 persons who were screened, 502 ( 5.7 percent) started the run-in phase. Of these, 459 (91.4 percent) were randomized. Base-line characteristics were similar in the three diet groups ( Table 2 ).

\section{Adherence}

The percentages of subjects who completed the intervention phase in the control, fruits-and-vegetables, and combination groups were 95.5, 97.4, and 98.7 percent, respectively. In the three groups, attendance at on-site meals was 95.8, 95.4, and 96.1 percent, and according to the subjects' own reports,
Table 3. 24-Hour Urinary Excretion of Potassium, Magnesium, Urea Nitrogen, Calcium, Phosphorus, and Sodium during the Run-In and Intervention Phases, AcCording to Diet.*

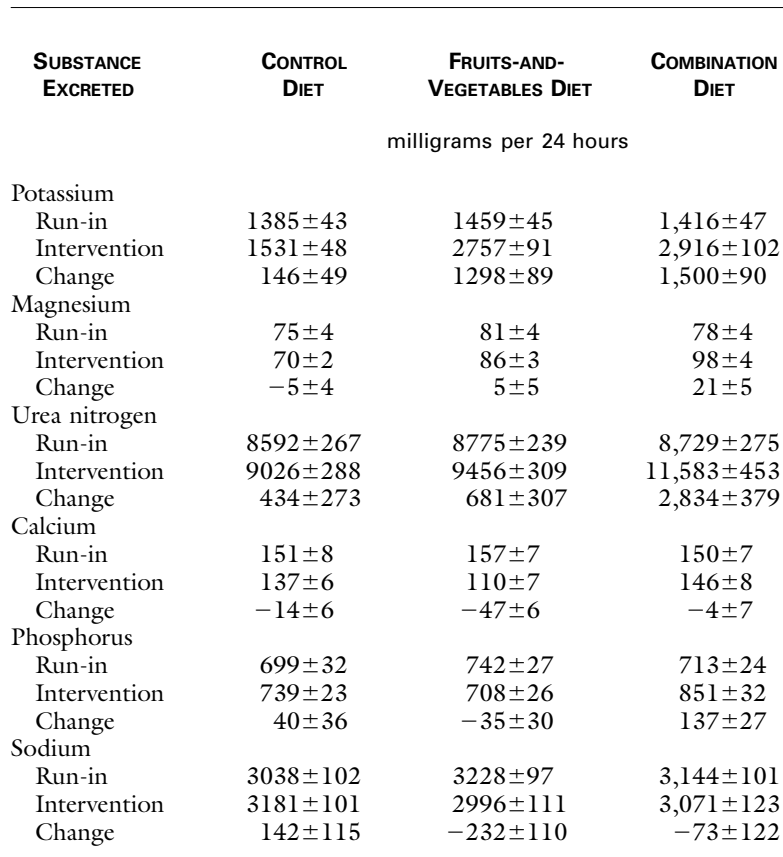

*Data were available for 113 to 122 subjects in each diet group. Plusminus values are means \pm SE. To convert values to millimoles per day, multiply by 0.025577 for potassium, 0.041144 for magnesium, 0.024951 for calcium, 0.032285 for phosphorus, and 0.043498 for sodium. To convert values for urea nitrogen to millimoles per day of urea, multiply by 0.0357 .

there was perfect adherence to the study diets (all study foods and no nonstudy foods eaten) on 94.6, 93.9, and 93.2 percent of person-days.

Urinary potassium excretion increased substantially from the run-in phase to the intervention phase in the fruits-and-vegetables and combination groups (Table 3), and magnesium excretion increased in the combination group. Urinary urea nitrogen excretion, which is indicative of total protein intake, increased substantially with the combination diet. Urinary calcium excretion decreased in the control and fruits-and-vegetables groups. Urinary phosphorus excretion increased substantially in the combination group. In each group, urinary sodium excretion changed little between the run-in and intervention phases. The mean changes in weight from the end of run-in to the end of intervention were $-0.1 \mathrm{~kg}$, $-0.3 \mathrm{~kg}$, and $-0.4 \mathrm{~kg}$ in the control, fruits-and-vegetables, and combination groups, respectively. Mean changes in alcohol consumption and physical activity were small and similar in the three groups (data not shown). 
Table 4. Comparisons of Mean Changes in Blood Pressure between Diets in All Subjects and in Subgroups Defined by Sex, Minority Status, and Hypertensive Status.*

\begin{tabular}{|c|c|c|c|c|c|c|}
\hline \multirow[t]{2}{*}{ Categoryt } & \multirow{2}{*}{$\begin{array}{c}\text { Change IN } \\
\text { Combination Group } \\
\text { Minus Change IN } \\
\text { Control Group } \\
(97.5 \% \mathrm{Cl}) \\
\mathrm{mm} \mathrm{Hg}\end{array}$} & \multirow[t]{2}{*}{ P Value } & \multirow{2}{*}{$\begin{array}{c}\text { Change in } \\
\text { Combination Group } \\
\text { Minus Change IN } \\
\text { Fruits-AND-VeGetables } \\
\text { Group }(97.5 \% \text { Cl) } \\
\text { mm Hg }\end{array}$} & \multirow[t]{2}{*}{ P Value } & $\begin{array}{c}\text { Change in Fruits-And- } \\
\text { Vegetables Group } \\
\text { MinUs ChanGe iN } \\
\text { Control Group } \\
(97.5 \% \mathrm{Cl})\end{array}$ & \multirow[t]{2}{*}{ P VALUe } \\
\hline & & & & & $\mathrm{mm} \mathrm{Hg}$ & \\
\hline \multicolumn{7}{|l|}{ Systolic pressure } \\
\hline All subjects $(n=459)$ & $-5.5(-7.4$ to -3.7$)$ & $<0.001$ & $-2.7(-4.6$ to -0.9$)$ & 0.001 & $-2.8(-4.7$ to -0.9$)$ & $<0.001$ \\
\hline $\operatorname{Men}(n=234)$ & $-4.9(-7.3$ to -2.5$)$ & $<0.001$ & $-1.6(-4.0$ to 0.8$)$ & 0.13 & $-3.3(-5.6$ to -0.9$)$ & 0.002 \\
\hline Women $(n=225)$ & $-6.2(-9.2$ to -3.3$)$ & $<0.001$ & $-3.9(-6.9$ to -1.0$)$ & 0.003 & $-2.3(-5.3$ to 0.7$)$ & 0.08 \\
\hline Minority $(n=303) \ddagger$ & $-6.8(-9.2$ to -4.4$)$ & $<0.001$ & $-3.2(-5.6$ to -0.8$)$ & 0.003 & $-3.6(-6.1$ to -1.2$)$ & 0.001 \\
\hline Nonminority $(n=156) \ddagger$ & $-3.0(-5.9$ to -0.1$)$ & 0.02 & $-1.9(-4.8$ to 1.0$)$ & 0.13 & $-1.1(-3.9$ to 1.7$)$ & 0.38 \\
\hline Nonhypertensive $(n=326) \S$ & $-3.5(-5.3$ to -1.6$)$ & $<0.001$ & $-2.7(-4.5$ to -0.8$)$ & 0.001 & $-0.8(-2.7$ to 1.1$)$ & 0.33 \\
\hline Hypertensive $(\mathrm{n}=133)$ & $-11.4(-15.9$ to -6.9$)$ & $<0.001$ & $-4.1(-8.6$ to 0.3$)$ & 0.04 & $-7.2(-11.4$ to -3.0$)$ & $<0.001$ \\
\hline \multicolumn{7}{|l|}{ Diastolic pressure } \\
\hline All subjects $(n=459)$ & $-3.0(-4.3$ to -1.6$)$ & $<0.001$ & $-1.9(-3.3$ to -0.6$)$ & 0.002 & $-1.1(-2.4$ to 0.3$)$ & 0.07 \\
\hline $\operatorname{Men}(n=234)$ & $-3.3(-5.1$ to -1.5$)$ & $<0.001$ & $-1.3(-3.2$ to 0.5$)$ & 0.10 & $-2.0(-3.7$ to -0.2$)$ & 0.01 \\
\hline Women $(\mathrm{n}=225)$ & $-2.7(-4.8$ to -0.7$)$ & 0.003 & $-2.5(-4.6$ to -0.5$)$ & 0.006 & $-0.2(-2.3$ to 1.9$)$ & 0.83 \\
\hline Minority $(\mathrm{n}=303) \ddagger$ & $-3.5(-5.2$ to -1.8$)$ & $<0.001$ & $-2.1(-3.8$ to -0.4$)$ & 0.007 & $-1.4(-3.2$ to 0.3$)$ & 0.07 \\
\hline Nonminority $(\mathrm{n}=156) \ddagger$ & $-2.0(-4.2$ to 0.2$)$ & 0.04 & $-1.6(-3.8$ to 0.5$)$ & 0.09 & $-0.4(-2.5$ to 1.7$)$ & 0.70 \\
\hline Nonhypertensive $(n=326)$ S & $-2.1(-3.6$ to -0.5$)$ & 0.003 & $-1.8(-3.4$ to -0.3$)$ & 0.009 & $-0.3(-1.9$ to 1.3$)$ & 0.71 \\
\hline Hypertensive $(\mathrm{n}=133)$ & $-5.5(-8.2$ to -2.7$)$ & $<0.001$ & $-2.6(-5.4$ to 0.1$)$ & 0.03 & $-2.8(-5.4$ to -0.3$)$ & 0.01 \\
\hline
\end{tabular}

${ }^{*}$ Mean values have been adjusted for clinical center. A P value of $<0.025$ was considered to indicate statistical significance. CI denotes confidence interval Confidence intervals of 97.5 percent are given because they are consistent with the adjustment for multiple comparisons.

†The mean base-line blood pressure was $131.3 / 84.7 \mathrm{~mm} \mathrm{Hg}$ for all subjects, $129.6 / 84.8 \mathrm{~mm} \mathrm{Hg}$ for men, $133.0 / 84.5 \mathrm{~mm} \mathrm{Hg}$ for women, $131.5 / 84.8 \mathrm{~mm} \mathrm{Hg}$ for members of minority groups, $130.9 / 84.5 \mathrm{~mm} \mathrm{Hg}$ for members of nonminority groups, $126.2 / 83.0 \mathrm{~mm} \mathrm{Hg}$ for subjects without hypertension, and $143.7 / 88.8 \mathrm{~mm} \mathrm{Hg}$ for subjects with hypertension.

¥Minority denotes blacks and members of other minority groups; nonminority denotes non-Hispanic whites.

$\$$ Hypertension was defined as a base-line systolic blood pressure $\geqslant 140 \mathrm{~mm} \mathrm{Hg}$ or a diastolic blood pressure $\geqslant 90 \mathrm{~mm} \mathrm{Hg}$; nonhypertension was defined as a base-line systolic blood pressure of $<140 \mathrm{~mm} \mathrm{Hg}$ and a diastolic blood pressure of $<90 \mathrm{~mm} \mathrm{Hg}$.

\section{Blood Pressure}

For systolic and diastolic blood pressure, a gradient across diets was evident. Table 4 shows average between-diet differences in the change in blood pressure. The combination diet reduced systolic blood pressure by $5.5 \mathrm{~mm} \mathrm{Hg}$ more and diastolic blood pressure by $3.0 \mathrm{~mm} \mathrm{Hg}$ more than the control diet did $(\mathrm{P}<0.001$ for each). The reductions with the fruits-and-vegetables diet were $2.8 \mathrm{~mm} \mathrm{Hg}(\mathrm{P}<0.001)$ and 1.1 $\mathrm{mm} \mathrm{Hg}$ greater than with the control diet $(\mathrm{P}=0.07)$. When compared with the fruits-and-vegetables diet, the combination diet reduced systolic blood pressure by $2.7 \mathrm{~mm} \mathrm{Hg}$ more $(\mathrm{P}=0.00 \mathrm{l})$ and diastolic blood pressure by $1.9 \mathrm{~mm} \mathrm{Hg}$ more $(\mathrm{P}=0.002)$. Results were similar after adjustment for changes in weight and urinary sodium excretion. The reductions in blood pressure with the fruits-and-vegetables and combination diets were achieved after two weeks and sustained for six more weeks (Fig. 1).

In subgroup analyses (Table 4 ), the pattern of differences between diets was similar to that of the entire sample; however, the differences were not always statistically significant. Although between-diet differences were greater in minority than nonminority subjects, interaction between minority status and diet was not significant. There was no evidence of interaction between sex and diet.

Both in subjects with hypertension and in those without hypertension, the combination diet reduced blood pressure more than the fruits-and-vegetables or the control diet. In each pairwise contrast, subjects with hypertension had greater reductions in blood pressure than subjects without hypertension. The interaction between hypertensive status and diet was significant for systolic blood pressure $(\mathrm{P}<0.001)$ and marginally significant for diastolic blood pressure $(\mathrm{P}=0.03)$.

Ambulatory blood-pressure recordings were available for 345 (95 percent) of the subjects in the last four enrollment groups. The combination diet reduced mean 24-hour ambulatory systolic blood pressure by $4.5 \mathrm{~mm} \mathrm{Hg}$ more than the control diet did and diastolic blood pressure by $2.7 \mathrm{~mm} \mathrm{Hg}$ more $(\mathrm{P}<0.001$ for each $)$. The corresponding reductions with the fruits-and-vegetables diet were $3.1 \mathrm{~mm} \mathrm{Hg}$ more $(\mathrm{P}=0.001)$ and $2.1 \mathrm{~mm} \mathrm{Hg}$ more $(\mathrm{P}=0.002)$.

\section{Other Effects}

Cholecystitis developed in one subject on the control diet. During the run-in phase, moderate or 


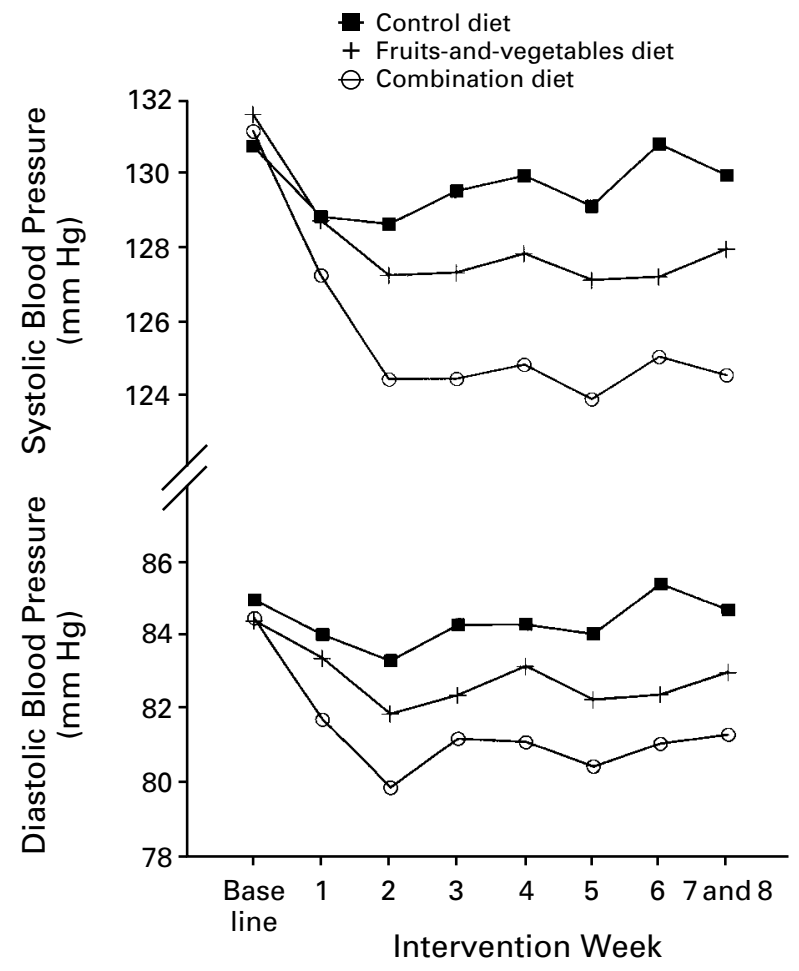

Figure 1. Mean Systolic and Diastolic Blood Pressures at Base Line and during Each Intervention Week, According to Diet, for 379 Subjects with Complete Sets of Weekly Blood-Pressure Measurements.

severe constipation during the preceding month was reported by 9 percent of the subjects. At the end of the intervention phase, constipation was reported by $10.1,5.4$, and 4.0 percent of the subjects eating the control, fruits-and-vegetables, and combination diets, respectively. Otherwise, the occurrence of gastrointestinal symptoms was infrequent and similar for all the diets.

\section{DISCUSSION}

This trial demonstrated that certain dietary patterns can favorably affect blood pressure in adults with average systolic blood pressures of less than $160 \mathrm{~mm} \mathrm{Hg}$ and diastolic blood pressures of 80 to $95 \mathrm{~mm} \mathrm{Hg}$. Specifically, a diet rich in fruits, vegetables, and low-fat dairy products and with reduced saturated and total fat lowered systolic blood pressure by $5.5 \mathrm{~mm} \mathrm{Hg}$ and diastolic blood pressure by $3.0 \mathrm{~mm} \mathrm{Hg}$ more than a control diet. A diet rich in fruits and vegetables also reduced blood pressure, but to a lesser extent. The gradient of blood-pressure reduction across diets indicates that some aspects of the fruits-and-vegetables diet reduced blood pressure and that additional aspects of the combination diet reduced it further. The trial was not de- signed, however, to identify the effective and ineffective components of the diets. Nonetheless, known diet-related determinants of blood pressure (sodium chloride, body weight, and alcohol) could not have accounted for the reductions in blood pressure, because changes in these potential confounders were small and similar for all the diets.

Other important findings were that the reduction in blood pressure began within two weeks and was maintained for the next six weeks. Furthermore, the pattern of reductions in blood pressure among the diets was similar in men, women, and members and nonmembers of minority groups and in analyses using average 24-hour ambulatory blood pressure as the outcome. Also, rates of attendance, subjects' own reports of food consumption, and patterns of urinary electrolyte and urea nitrogen excretion indicated that adherence to the assigned diets was excellent.

Unexpected observations were a prominent reduction in urinary calcium excretion from the run-in to the intervention phase with the fruits-and-vegetables diet and no increase in calcium excretion with the combination diet. This pattern of findings can potentially be explained by the high fiber content of these two diets, which may have impeded calcium absorption. ${ }^{22}$ Nonetheless, the substantial increase in urinary phosphorus excretion with the combination diet suggests that the subjects in this group did consume more dairy products than the other participants.

The results of the DASH trial should be broadly applicable to the U.S. population. The study population was demographically heterogeneous, with a range of blood pressures that includes approximately 40 percent of U.S. adults. ${ }^{1}$ Forty-nine percent of the subjects were women, 60 percent were black, and 37 percent had household incomes of less than $\$ 30,000$ per year. By using commonly available foods, including meats, the trial tested dietary patterns that the general U.S. population potentially could adopt. In the fruits-and-vegetables and combination diets, the 8 to 10 servings per day of fruits and vegetables are approximately twice the average of 4.3 servings consumed by U.S. adults ${ }^{23}$ and are higher than the 5 to 7 servings per day recommended in the Dietary Guidelines for Americans.24 In the combination diet, the 2.7 servings per day of dairy products (predominantly low-fat) are almost twice the current average consumption of approximately 1.5 servings per day ${ }^{25}$ but are within the dietary guidelines' recommendation of 2 to 3 servings per day.

It is important to emphasize that DASH was an 11-week feeding study. As such, it was not designed to assess either adherence to the diets among people selecting their own food or the long-term effects of the diets on blood pressure and clinical cardiovascular events. Nonetheless, the trial results have several clinical and public health implications. 
First, the blood-pressure reductions observed in the subjects without hypertension suggest that following the DASH combination diet might be an effective nutritional approach to preventing hypertension. It is noteworthy that the blood-pressure reductions occurred in the setting of stable weight, a sodium intake of approximately $3 \mathrm{~g}$ per day, and consumption of two or fewer alcoholic drinks per day. Hence, adoption of the DASH combination diet should complement, rather than supplant, what is currently recommended (weight control, reduced sodium chloride intake, and reduced alcohol consumption).

Second, in the subjects with hypertension, the reduction in blood pressure with the combination diet was similar in magnitude to that observed in trials of drug monotherapy for mild hypertension. ${ }^{26}$ Hence, following the DASH combination diet might be an effective alternative to drug therapy in people with stage I hypertension and might prevent or delay the initiation of drug therapy in people with blood-pressure levels that straddle the thresholds for drug treatment.

Third, adoption of the combination diet could potentially shift the population distribution of blood pressure downward, reducing the occurrence of blood-pressure-related cardiovascular disease. ${ }^{27,28} \mathrm{It}$ is estimated that a population-wide reduction in systolic or diastolic blood pressure of the magnitude observed with the combination diet would reduce incident coronary heart disease by approximately 15 percent and stroke by approximately 27 percent. ${ }^{29}$

In conclusion, a diet rich in fruits, vegetables, and low-fat dairy foods and with reduced saturated and total fat can substantially lower blood pressure. Such a diet offers an additional nutritional approach to the prevention and treatment of hypertension.

Supported by grants (HL50981, HL50968, HL50972, HL50977, HL50982, HL02642, RR02635, and RR00722) from the National Heart, Lung, and Blood Institute, the Office of Research on Minority Health, and the National Center for Research Resources of the National Institutes of Health.

Presented at the 69th Scientific Sessions of the American Heart Association, New Orleans, November 13, 1996.

We are indebted to the trial participants for their sustained commitment to DASH; to the following companies, which donated food: Best Foods, Campbell's Soup Company, Coca-Cola Foods Company, Comstock Michigan Fruit, The Dannon Company, Dole Food Company, H.J. Heinz Company, Harris Teeter Company, Hershey Foods Corporation, Lifelines Technology, Inc., McCormick \& Company, Inc., Nabisco Foods Group, Ocean Spray Cranberries, Inc., Procter \& Gamble, Quaker Oats Company, Ralston Foods, Sunkist Growers, Vandenbergh Foods, and Wawona Frozen Foods; and to the external Protocol Review Committee and Data and Safety Monitoring Board, which included Jerome Cohen, M.D., Patricia Elmer, Ph.D., James Neaton, Ph.D., Jeremiah Stamler, M.D. (chair), Phyllis Stumbo, Ph.D., and Jackson Wright, M.D., Ph.D.

\section{APPENDIX}

In addition to the authors, the DASH Collaborative Research Group includes the following institutions and individuals: Division of Epidemiology and Clinical Applications, National Heart, Lung, and Blood Institute, Bethesda, Md. (sponsor) - M.A. Proschan; Kaiser Permanente Center for Health Research, Portland, Oreg. (coordinating center) - P. LaChance, R. Laws, C. Eddy, J. Rice, K. Linton, L. Haworth, N. Adams, K. Pearson, L. Diller, and J. Taylor; Brigham and Women's Hospital and Harvard Medical School, Boston (clinical center) - P. Conlin, L. Jaffe, J. McKnight, M. MacDonald, K. Nauth, and Y. Courtney; Duke University Medical Center, Durham, N.C. (clinical center) - M. Drezner, C. Bales, L. Carter, J. Ard, C. Plaisted, K. Hoben, S. Norris, P. Reams, K. Aicher, and R. Fike; Pennington Biomedical Research Center, Louisiana State University, Baton Rouge (clinical center) - D.H. Ryan, C.M. Champagne, P.J. Wozniak, B. McGee, S. Crawford, and B.M. Kennedy; Johns Hopkins University, Baltimore (clinical center) - B. Caballero, S. Kumanyika, S. Jee, J. Charleston, P. McCarron, S. Cappelli, B. Harnish, and P. Coleman; Virginia Polytechnic Institute, Blacksburg (food-analysis coordinating center) - K.K. Stewart and K. Phillips; Oregon Health Sciences University, Portland (central laboratory) - D. McCarron, J.-B. Roullet, and R. Illingworth; Beltsville Human Nutrition Research Center, U.S. Department of Agriculture, Beltsville, Md. (research kitchen for Johns Hopkins Clinical Center) - S. Burns, E. Lashley, and J.T. Spence.

\section{REFERENCES}

1. Burt VL, Whelton P, Roccella EJ, et al. Prevalence of hypertension in the US adult population: results from the Third National Health and $\mathrm{Nu}$ trition Examination Survey, 1988-1991. Hypertension 1995;25:305-13. 2. The Joint National Committee on Detection, Evaluation, and Treatment of High Blood Pressure. The fifth report of the Joint National Committee on Detection, Evaluation, and Treatment of High Blood Pressure (JNC V). Arch Intern Med 1993;153:154-83.

3. Working Group on Primary Prevention of Hypertension. National High Blood Pressure Education Program Working Group report on primary prevention of hypertension. Arch Intern Med 1993;153:186-208.

4. Sacks FM, Rosner B, Kass EH. Blood pressure in vegetarians. Am J Epidemiol 1974;100:390-8.

5. Rouse IL, Beilin LJ, Armstrong BK, Vandongen R. Blood-pressure-lowering effect of a vegetarian diet: controlled trial in normotensive subjects. Lancet 1983;1:5-10.

6. Margetts BM, Beilin LJ, Vandongen R, Armstrong BK. Vegetarian diet in mild hypertension: a randomised controlled trial. BMJ 1986;293:1468 71

7. Ascherio A, Rimm EB, Giovannucci EL, et al. A prospective study of nutritional factors and hypertension among US men. Circulation 1992;86: 1475-84.

8. Harlan WR, Hull AL, Schmouder RL, Landis JR, Thompson FE, Larkin FA. Blood pressure and nutrition in adults: the National Health and Nutrition Examination survey. Am J Epidemiol 1984;120:17-28.

9. Stamler J, Caggiula A, Grandits GA, Kjelsberg M, Cutler JA. Relation ship to blood pressure of combinations of dietary macronutrients: findings of the Multiple Risk Factor Intervention Trial (MRFIT). Circulation 1996; 94:2417-23.

10. Stamler J, Elliott $\mathrm{P}$, Kesteloot $\mathrm{H}$, et al. Inverse relation of dietary protein markers with blood pressure: findings for 10020 men and women in the INTERSALT study. Circulation 1996;94:1629-34.

11. Obarzanek E, Velletri PA, Cutler JA. Dietary protein and blood pressure. JAMA 1996;275:1598-603.

12. The Trials of Hypertension Prevention Collaborative Research Group. The effects of nonpharmacologic interventions on blood pressure of persons with high normal levels: results of the Trials of Hypertension Prevention, Phase I. JAMA 1992;267:1213-20. [Erratum, JAMA 1992;267: 2330.]

13. Whelton PK. Potassium and blood pressure. In: Izzo JL, Black HR, eds. Hypertension primer: the essentials of hypertension. Dallas: American Heart Association, 1993.

14. Allender PS, Cutler JA, Follmann D, Cappuccio FP, Pryer J, Elliott P. Dietary calcium and blood pressure: a meta-analysis of randomized clinical trials. Ann Intern Med 1996;124:825-31.

15. Whelton PK, Klag MJ. Magnesium and blood pressure: review of the epidemiologic and clinical trial experience. Am J Cardiol 1989;63:26G$30 \mathrm{G}$.

16. Eliasson K, Ryttig KR, Hylander B, Rossner S. A dietary fibre supplement in the treatment of mild hypertension: a randomized, double-blind, placebo-controlled trial. J Hypertens 1992;10:195-9.

17. Brussaard JH, van Raaij JMA, Stasse-Wolthuis M, Katan MB, Hautvast JGAJ. Blood pressure and diet in normotensive volunteers: absence 
of an effect of dietary fiber, protein, or fat. Am J Clin Nutr 1981;34: 2023-9

18. Morris MC, Sacks FM. Dietary fats and blood pressure. In: Swales JD, ed. Textbook of hypertension. Oxford, England: Blackwell, 1994: 605-18.

19. Sacks FM, Obarzanek E, Windhauser MM, et al. Rationale and design of the Dietary Approaches to Stop Hypertension trial (DASH): a multicenter controlled-feeding study of dietary patterns to lower blood pressure. Ann Epidemiol 1995;5:108-18

20. Blair SN, Haskell WL, Ho P, et al. Assessment of habitual physical activity by a seven-day recall in a community survey and controlled experiments. Am J Epidemiol 1985;122:794-804

21. National Center for Health Statistics, Carroll MD, Abraham S, Dresser CM. Dietary intake source data: United States, 1976-80. Vital and health statistics. Series 11. No. 231. Washington, D.C.: Government Printing Office, 1983. (DHHS publication no. (PHS) 83-1681.)

22. National Research Council. Diet and health: implications for reducing chronic disease risk. Washington, D.C.: National Academy Press, 1989 301.

23. Krebs-Smith SM, Cook A, Subar AF, Cleveland L, Friday J. US adults' fruit and vegetable intakes, 1989 to 1991: a revised baseline for the Healthy People 2000 objective. Am J Public Health 1995;85:1623-9.
24. Department of Agriculture, Department of Health and Human Services. Nutrition and your health: dietary guidelines for Americans. 4th ed. Washington, D.C.: Government Printing Office, 1995. (Home and garden bulletin no. 232.)

25. Cleveland LE, Goldman JD, Borrud LG. Data tables: results from U.S.D.A.'s 1994 Continuing Survey of Food Intakes by Individuals and the 1994 Diet and Health Knowledge Survey. Riverdale, Md.: Food Surveys Research Group, 1996.

26. The Treatment of Mild Hypertension Research Group. The Treatment of Mild Hypertension Study: a randomized, placebo-controlled trial of a nutritional-hygienic regimen along with various drug monotherapies. Arch Intern Med 1991;151:1413-23.

27. Stamler J, Rose G, Stamler R, Elliott P, Dyer A, Marmot M. INTER SALT study findings: public health and medical care implications. Hypertension 1989;14:570-7.

28. Stamler J, Stamler R, Neaton JD. Blood pressure, systolic and diastolic, and cardiovascular risks: US population data. Arch Intern Med 1993;153 598-615.

29. Cutler JA, Psaty BM, MacMahon S, Furberg CD. Public health issues in hypertension control: what has been learned from clinical trials. In:

Laragh JH, Brenner BM, eds. Hypertension: pathophysiology, diagnosis, and management. 2nd ed. Vol. 1. New York: Raven Press, 1995:253-70. 